African Journal of Business and Economic Development | ISSN: 2782-7658

Journal DOI: www.doi.org/10.46654/AJBED

Vol. 1, Issue 2 (February, 2021) | www.ijaar.org

Article DOI: www.doi.org/10.46654/AJBED.1218

\title{
EMPIRICAL ASSESSMENT OF PUBLIC SECTOR REFORM IN NIGERIA: A TREND ANALYSIS BETWEEN 2000 AND 2015
}

\author{
ONODUGO, Vincent Aghaegbunam \\ Department of Management, University of Nigeria, Enugu Campus
}

NWAKOBY, Ifeoma

Department of Banking and Finance, University of Nigeria, Enugu Campus

OFOEGBU Grace N.

Department of Accountancy, University of Nigeria, Enugu Campus

EGBO, Obiamaka P.

Department of Banking and Finance, University of Nigeria, Enugu Campus

OKOYEUZU, Chinwe

Department of Banking and Finance, University of Nigeria, Enugu Campus

\begin{abstract}
This study assessed the impact of public sector reforms programmes on the human resources management and civil service of the Nigerian public service. Data for the study were mainly secondary data complemented with primary data collected from stakeholders in the public service that have experienced various reforms in their career. Findings suggest that the impact of reforms on HRM and CSR were largely marginal. The positives of the reforms are mainly in the areas of improvement in salaries and functionality of pension and retirement benefits by making it contributory. These improvements in emoluments narrowed the incentives between public and private sectors and tend to attract skilled hands to the public sector that otherwise would not have been the case. However, all other policy initiatives that were aimed at ensuring effective and efficient use of scarce resources, transparency and accountability by civil servants, incentives and promotion by merit and value for money were at various stages of policy reversal, delayed implementation, and outright abandonment by compromising civil servants that selectively implement only those reforms that suits and benefits their interests. Further, successive regimes after that of former President Olusegun Obasanjo (1999-2007) who initiated most of the reforms, did not have or could not provide enough political will to sustain the benefits and the tempo of these reforms.
\end{abstract}

Key Words: Public reforms; Human resources management; Civil service; Public sector 


\subsection{Background of the Study}

Public service, that was hitherto not given its pride of place in public discourse, has recently taken a front burner position in development commentary and discourse. This shift in perception flow from more recent and inclusive analyses which highlight the critical and catalytic role of bureaucracy in providing the relevant data for policy making; and more critically, for translating policies and programmes of government into service delivery and concrete welfare results (Olaopa, 2013;Anazodo, Okoye and Chukwuemeka, 2012). In other words, no state leadership can perform beyond the space allowed it by the machinery of government, generally referred to as the civil or public service (Adewunmi and Idowu ,2012). Suleiman (2010) rightly argues that even if the political leadership fails, it is incumbent on the public service to steer it in the right direction. This is because the while politicians come and go, the public service status is permanent. Moreover, they are supposed to be custodians and repository of policies and programmes to ensure continuity and, where necessary, track changes.

Nigeria, after several years of experimentation with various models of development, came to terms with the fact that it has made the least of its huge resources and was regarded in some circles as a geographical scandal and economic paradox. The huge infrastructural gap and the dismal performance of the country in key indices of development is at variance with the $\$ 300$ billion dollars generated from crude oil sales between 1970 and 1999 (Okonjo-Iweala, 2012). Unfortunately, the civil service that ought to stabilize and guide the polity and governance was largely perceived as unaccountable, corrupt, ineffective and inefficient (El-rufai 2011).

Consequently, in 1999, Nigeria had little choice than to embark on a holistic public service reforms. These reforms were well received locally and internationally because they were done at the instance of a populist democratic dispensation. After a decade and a half of public sector reforms in Nigeria, which gulped a lot of resources, the outputs and impacts have elicited varying reactions and evaluations. The result of the just concluded elections seem to show that the people expected more than what was given by the ruling party.

It is against this backdrop that the study seeks to assess the effectiveness of the public sector reform that took place between 2000 and 2015. The intention is to ascertain what went well and what did not, and why. It is expected that findings from the study will shape and guide policy planning and implementation in Nigeria going forward.

\subsection{Statement of the Problem and Justification of the Study}

The major macroeconomic and developmental goals as well as their implementation strategies had been articulated in a planning document known as the National Economic Empowerment and Development Strategy (NEEDS) which had been developed in the first phase of public sector reforms in 2004. Unfortunately, many of the reform programmes, though promising at the early stages, have not realised their objectives. Critics complain that the benefits of the lauded economic growth have not trickled down to the poor. As such, poverty and unemployment are still major challenges facing the economy. Moreover, effective implementation of some of the reforms had been hindered by corruption. According to the 2013 Transparency International's Global Corruption Report, Nigeria's ranking worsened as it moved from $139^{\text {th }}$ out of 174 countries in 2012 to $144^{\text {th }}$ out of 175 countries (African Development Bank, 2014). A tragic outcome of this pervasive corruption, particularly in the public sector, is that resources which would have been saved from some of 
the reform programmes (for example, privatisation and monetisation exercises) and utilised to improve existing deteriorating social and physical infrastructure or provide new ones have been diverted into private pockets (Monye-Emina, 2012).

\subsection{Objectives and delimitation of the Study}

The main objective of this study is to assess the extent to which public sector reforms have fared in the last fifteen years. The public sector reforms covered five thematic areas thus: i) Pubic Finance Management (PFM); ii) Policy and Planning Framework; (PPF) iii) Human Resources Management (HRM); iv) Performance Management System and Monitoring and Evaluation (PMS and M\&E), and v) Civil Service Reform ( CSR). Since it will be unwieldy to cover the whole five thematic areas, this study delimits itself to two key areas of CSR and HRM.

The specific objectives of the study are to:

1. Assess the impact of the public sector reforms on the Nigerian civil service operations, and,

2. Ascertain the extent the public reforms influenced the human resources management of the public service.

\subsection{Literature Review}

\subsection{Conceptual Background}

The public sector of a country is the means through which the developmental goals of the government are achieved. These goals are ideally geared towards the advancement of the welfare of the citizenry such as infrastructural development, unemployment reduction, revenue generation, as well as fiscal and monetary policies), which benefit the citizenry at large. Accordingly, an effective public sector has come to be recognised by many developing countries as being central to achieving socio-economic development (Ojeifo \& IleSanmi, 2015; Mbecke, 2016; Ali'nska, Filipiak, \& Kosztowniak, 2018). This then informs the great and enduring interest in the functioning of the public sector. Furthermore, when the public sector of a country is effective in achieving its objectives, the government is seen as successful, and likely to be re-elected. To that end, Rodman (1968) and Gurara, et al. (2017) assert that the major challenge faced by less developed countries is not so much lack of capital or foreign aid, but a failure of the public sector structure.

Over the years, the concept of how the public sector should function has gone through fundamental changes and resulted in constant reforms in most countries. The last three decades saw a huge reversal in what constituted good governance, and this led to varied attempts to change the concept of public sector administration (Katsamunska, 2012). The traditional public sector model conceived by one of the greatest influences on the theory of public administration, Max Weber, had come to be seen as largely bureaucratic in nature. Hence, the need to adjust to an increasingly dynamic world resulted in what is now referred to as the new public management (hereafter NPM).

Reforms imply a significant change from previous ways of doing things (Fidrmuc \& Noury, 2003). Accordingly, advocates of the NPM proposed public sector reforms that involved adopting private sector principles, and resulted in changes in institutional structures, 
processes, and behaviour (Omoyefa, 2008). In Africa, such reforms were typically influenced by external forces such as donor agencies who made them part of the conditionalities for loans given to the countries (Therkildsen, 2001). Nigeria was not left out of the reform fad as there have been major reforms pre- and post-independence in the different areas of the public sector.

Public Sector Reform (PSR) is an umbrella word that bellies about six major reform subsets; these include public financial management (PFM) reforms, legal and judicial reforms, civil service reform (CSR), Governance decentralization reforms, revenue management reforms, and anti-corruption (see also IEG 2008). PSRs are targeted at addressing complex and illdefined problems within parts or all of the public, which is itself an interdependent system embedded within the wider systems of society and culture. The reforms typically seek to address four main thematic areas: (1) reforms of the role of the state, (2) central government reforms, (3) civil service system reform and (4) reforms to accountability and oversight mechanisms (Scott, 2011).

There is an abundance of literature on public reforms. Much of this literature focuses on the challenges of effective and efficient government in the developed countries. Politt and Bouckaert (2004) provide a broadly cited review on the experience of public sector reforms in ten OECD countries (USA, UK, Sweden, the Netherlands, New Zealand, Germany, France, Finland, Canada, Australia). The study infers that public sector reform is usually a top down reaction by the political system and raises concerns for fiscal pressures and issues of legitimacy. Employing a framework that portrays the political system as having a triangular relationship with the system of public administration and the market economy, they described the diverse approaches to public sector reforms across the ten countries - a mix of "modernization, minimization, marketization, and maintenance" to use their characterization. Any of these four reform approaches can be a stand-alone reform strategy, though most reform designs are usually a mix of two or more of these approaches.

Most of the available literature on PSR agrees that enormous technical and funding resources have been sunk into public service reforms worldwide but that the overall outcome has generally trailed behind expectations. PSR literature is replete with analysis of reforms of all sizes and designs implemented across several climes. The emphasis of these discussions typically centres on the technical designs and methodologies, evaluation indicators, and funding requirements. There is little attempt to explain why these reforms were instituted, what problems they were designed to solve and what theories of change underpin the particular reform design. Where an attempt is made to outline the basis for a reform and the problems and outcomes targeted, a critical analysis of the official rhetoric that seeks to justify the reform to the populace and the reform design often reveals a disconnect with the real target of the reform package. This incongruity results in disappointed expectations among the recipient of reforms, culminating in a loss of credibility and pervasive distrust of the efficacy of such reforms.

\subsection{Theoretical Framework}

The Nigerian civil service system inherited from the colonial masters in the 1960s was inspired by the Weberian Bureaucratic Model (Adamolekun, 2002). An understanding of the model will therefore help us better understand the inherent deficiencies of the model and the challenges that new reform ideas will have to address to proffer a superior framework than that bequeathed by the colonialists. The model is defined by Weber as a legal rational 
authority, embodied in civil service structures and laws. The primary goal of the model is to eliminate patrimonial, amateur and spoils system of administration. The common components of the model include entrance by examination, or other professionally approved qualifications, promotion by merit, job tenure, reasonable and predictable salaries, and administration based on written rules. By taking personnel decisions out of the hands of politicians, the bureaucratic model was expected to reduce patronage and clientelism. Stable employment and income are to diminish the temptations of corruption, while detailed rules and extensive paper trails provide means for rooting out malfeasance in the course of public service (Gerth and Mills 1946). This model with time became recalcitrant and retrogressive. It became so resistant to change and throws up a long and windy route to getting things done that it was labelled 'red-tapism'. Incumbents often blame delays to service delivery on pedantic adherence to extant rules and procedures. The latter created the need and watered the ground for emergence of the New Public Management Theory

The New Public Management Theory (NPM): The New Public Management Theory is supporting the introduction of private sector management principles, practices and incentive methods into the running of public institutions. It incorporates agency and governance theories. Maesschalck (2004) and Gruening (2001) explain that NPM is a movement to reform public sector organisations by removing politics from government institutions. This theory became imperative due to lack of financial discipline, excessive corruption and colossal wastes that became the order of the day in most public organisations. It is reasoned that if the principles that make private organisations succeed are applied to the running of public organisations that remarkable results will be the outcome. This Theory runs on the principles of merit, neutralitycompetent administration and sound financial management. This is the theory behind massive commercialisation and privatisation of the public enterprises in Nigeria; a move that witnessed huge transformations in telecommunication, aviation, hospitality, and entertainment industries.

\subsection{History of Nigerian Public Sector Reforms}

The history of public sector reforms in Nigeria has been a long and chequered one dating back to the 1930s. The reforms are usually designed as interventions directed at the structure, operations and procedures of the different arms of the public service with the purpose of transforming it to a multi-facetted agent of change as well as an instrument of national cohesion and socio-economic development. The reforms can be in the form of organizational restructuring of the public sector, Public personnel management, Public sector work place relations, Salary and remuneration reforms, employment/service reforms, and management and operational practices.

In terms of evolution, structure and features, a country's public sector is largely influenced by its socio-political, cultural, and historical experience. For any nation, the structure and features result from a complex interplay of its socio-economic aspirations, development objectives, cultural influences, political considerations, and the evolution of public service administration. For Nigeria, the public sector, including its structure and features, evolved from the country's colonial history being a former appendage of the British Empire. In the early colonial period (1914-1946), the system operated as a centralized military-civil-service type with British military field officers as the principal personnel. It also had an admixture of indigenous traditional and British values. Later constitutional and political developments influenced the outlook of the sector as it became decentralized between 1946 and 1966 with 
the emergence of Federal and Regional (later State) organs. From the period after independence the public sector in Nigeria dealt with a variety of governments and governance systems. These are civil, military, parliamentary, presidential, quasi-federal and semi-military. The military and quasi-federal has had the longest period and the most profound impact on the sector.

It is important to note that the history of reforms in Nigeria did not begin with the Obasanjo reform of the public sector (1999-2007). The sector had, on different occasions, been declared inefficient, wasteful and ineffective and fraught with political and bureaucratic abuses, thus necessitating the reforms. In its history, the country has made well over 15 reform attempts both major and minor. Some major ones include the 1988 National Planning Commission led reform that expanded government ministries and departments to the extent that government expenditure expanded from 29 per cent to about 50 per cent of GDP (Monye-Emina, 2012); the structural adjustment programme of the mid 80s and 90s that led to massive retrenchment of civil servants and injurious downsizing of the government, and Obasanjo's NEEDs, SEEDs, and LEEDs reforms (1999-2007).

Most of the reforms were offshoots of the reports of committees and commissions set up to examine the way the sector operated or were designed and implemented as wholesale reform agenda (mostly from external promoters). Most focused-on salaries and wages with a few giving attentions to the transformation of the public sector into a performance-oriented entity. Yet, others were set up to deal with complaints arising from some of the earlier reforms and sometimes ended up reversing earlier reform measures.

The reform experience in Nigeria, though often showing marked deviation from stated objectives, has recorded some landmark achievements that provide important fundamentals upon which future reform efforts can build on for success. These include the deregulation of the banking and telecom sectors which has led to growth hitherto unimagined for the sectors, such that Nigeria firms in these sectors now play in the global arena, deregulation of the downstream sector of the petroleum industry and the ongoing power sector reforms. Other gains are the passing of freedom of information bill which helps to hold public servants more accountable, as well as the petroleum industry bill just to mention a few. The generalized systemic reforms may have fallen short of expectations in Nigeria, but its paths are littered with pockets of landmark gains which hold out great promise for future reforms.

\subsection{Methodology}

The study made use of experimental study design, making use of mainly qualitative data. This design presents the situation prior to the reform programme and cross checks the resultant outcome of the reform intervention on the key work streams we are interested in. Data for this study was primarily obtained through secondary sources, supplemented with limited primary data. Secondary data were obtained from reports of previous related studies, books, and newspaper publications on public sector reforms in Nigeria, information, and data from the internet. The primary data on the other hand was sourced from the programme managers of some selected international organisations involved in public sector reforms in Nigeria and personnel of the Ministries, Department and Agencies (MDAs) that were involved in the on-going public sector reforms. 
Data instruments used for secondary data was content analysis of the reports from National Bureau of Statistics and reports of development partners involved in the reforms. Primary data were obtained by interview of some of the available programme managers involved in the programme. The resulting qualitative data from interview were used to triangulate the data obtained from secondary sources. The study results were presented in such a way that it described the situation prior to the reform, then mentioned the areas of intervention by the reform and finally captured how the reform impacted the various streams of reform focus.

\subsection{Presentation and Discussion of Findings}

To appreciate the impact of the reforms on the two key focal areas of the research we shall first present what the situation was before the intervention and what it turned into after the intervention.

\section{Human Resources Management}

Situation before reform: The public service represented the 'dead hand' of the government bureaucracy replete with aging workforce that is incompetent, corrupt, lazy and reformaverse. Incidence of ghost worker and absenteeism was high. The incentive structure trailed far below what obtains in the private sector which drives upwardly mobile competent employees farther from it. The civil service rules and schemes of service which guided the work of civil servants are archaic and moribund. Recruitment of staff to public service is based on patrimony and sectional sentiments and not on need and merit. Consequently, the public service grew by $350 \%$ between 1960 and 1999, over 60\% was above 40 years and $70 \%$ were unskilled. The results were poor service delivery and less value for the money spent on public utilities.

Reform Interventions agenda and programme of activities: The dimensions and thrust of the reform programme in this area include; improving the pay reform package to close the gap between it and the private sector; an Integrated Payroll and Personnel Information System (IPPIS) to establish a reliable database for the public service to facilitate manpower planning and eliminate record and payroll fraud; monetization of fringe benefits and pension reform to eliminate waste, enhance transparency and smoothen the exit of staff on retirement. Others include downsizing and rightsizing of public service to achieve a trim workforce fit for purpose and cost effective and professionalization of civil service by attracting competent hands from the organized private sector and systematic introduction of private sector values and principles in personnel management.

Outcome/Impact of the Reform: An analytical review of the impact of reform in this area within the period under review is largely minimal. The essential thrust of the reform which is to trim the workforce to efficient size and create a working ambience for civil servants to put in their best using private sector human resources management (HRM) principles could not be adopted. Specifically, the only thing that survived the first wave of reform acceptance was the slight increase in the pay of federal civil servants (Shonekan Committee of 2007) and the contributory pension reform of 2004. Both incentives, which fortuitously, happened when the global economic downturn negatively impacted on the private sector, encouraged moderately skilled staff to move from private sector to public service. This pay raise was however limited to the federal government level as states and LGAs were left to pay as they saw fit. Other outputs of this work stream such as IPPIS, monetisation of fringe benefits, right-sizing of 
public servants, restructuring of centralised personnel function domiciled with the Federal Civil service Commission to a more decentralised and professional HRM units, all suffered varying levels of policy reversal, delayed implementations, and discriminatory implementation. The result is that little has changed really in the personnel management of public service except that federal civil servants are remunerated slightly more than before even for the same work.

\section{Civil Service Reforms (CSR)}

Situation before reform: The civil service prior to reform was structurally dysfunctional. It was highly centralized, hierarchical, and rule-driven system which stifles individual initiative and muffles corporate accountability. The size of the Service was over bloated which saw the deployment of about 60 per cent of Federal Government spending to servicing the federal bureaucracy (including the National Assembly). There was a wide gap between the vision and mission of political leadership and the activities of the ministries, department, and agencies (MDAs) of the government. The result was epileptic, delayed, and low-quality services to the citizenry. There was disenchantment among the rank and file of the Service, with performance anchored on archaic schemes of service and public service rules. Since recruitment and career advancement were anchored on sentiments and cronyism not on merit and clearly laid down procedures, public servants were highly in-disciplined.

Reform agenda and areas of intervention: To achieve the goals of the service reforms the following programme of activities were embarked upon:

- Introducing of SERVICOM units and Service Charters which highlights to the public the services they are due to them and opportunities to seek redress where and when necessary. It serves as a feedback mechanism that helps to monitor the quality-ofservice delivery rendered to the public.

- Revision and update of financial regulation and Public Service Rules

- Giving tenure regime to the post of Directors and Permanent secretaries ${ }^{1}$

- Restructuring of the structure of MDAs. It requires that MDAs should have departments between 8 -4 and divisions between 2-4 per departments (Ogunrotifa, 2012; el-Rufai, 2011)

- Establishment of Bureau of Public Service Reform (BPSR) in 2003 to coordinate public service reforms

Outcome and Impact: Generally, the impact of the reform activities in this work stream is quite minimal. There are basically two take-aways of the reform activities in this area: First, is the perception to the public that the civil service care about and even attempt to plan for the improvement of the quality of services rendered to it through service charters and SERVICOM unit activities. Second, is the sense of equity and fairness associated with giving tenure to the offices of the director general (DG), director and permanent secretaries (PS). Beyond these, there is little impact of the other programme activities in this stream. The revision of the Public Service rules and Financial regulation are either not approved or widely

\footnotetext{
${ }^{1}$ Directors and permanent secretaries are required to serve for the first term of 4 years and where they perform well are required to serve another term of eight years.
} 
disseminated and enforced because there is no noticeable change in the conduct of civil servants as a result. The number of government agencies is still high with apparent functional duplication and overlap among various MDAs. Consequently, the size of government is still high, and the amount used in maintaining it still disproportionately high.

The preceding result of the study shows that reform interventions in both civil service and human resources work streams only achieved minimal results. These minimal outcomes are not so much that the programmes are not laudable but that there are inherent altitudinal and systemic bottlenecks that hindered effective results. For instance, most of the programmes target the fraudulent and incompetent practices of civil servants who are usually reluctant to implement them except the ones that bother on increase in emoluments and conditions of work. Further, because of the permanent status of civil servants, the reform drivers who are mainly politicians and their cronies come and go leaving these public servants behind to pick and choose reform programmes that suit them. Another hindrance is that the implementing civil servants see the reforms programmes as being imposed on them from the external. The consultants and programme managers that drive the reforms agenda tend adopt uniformly developed templates without involving the civil servants that will implement it. In the end, they do not own the programmes which get discarded when the reforms agents leave.

\subsection{Conclusion and Recommendation}

This study assessed the impact of public sector reforms programmes on the outcomes of the two work streams of human resources and civil service. Data for the study were mainly secondary data complemented with primary data collected from stakeholders in the public service that have orchestrated and experienced various reforms in their career. Findings suggest that the impact of reforms on HRM and CSR are largely marginal. The positives of the reforms are mainly in the areas of improvement in salaries and functionality of pension and retirement benefits by making it contributory. These improvements in emoluments narrowed the incentives between public and private sectors and tend to attract skilled hands to the public sector that otherwise would not have been the case. However, all other policy initiatives that were aimed at ensuring effective and efficient use of scarce resources, transparency and accountability by civil servants, incentives and promotion by merit and value for money were at various stages of policy reversal, delayed implementation, and outright abandonment by compromising civil servants that selectively implement only those reforms that suits and benefits their interests. What is more, successive regimes following that of former President Olusegun Obasanjo (1999-2007) who initiated most of the reforms, did not have or could not provide enough political will to sustain the benefits and the tempo of these reforms. It is our informed opinion that involving public servants in formulating these policies at the outset would enhance its uptake and ownership and thus enhancing chances of sustainability. 


\section{Recommendations}

Sequel to the core lessons learnt and highlighted in the study, it is our informed opinion that the following recommendations are pertinent;

1. Going forward, Human Resource Management reforms in the public service should be anchored around political leadership, public service administrators and Consultants. Consultants offer support services from time to time but Civil servants have a career to protect until their retirement or exit from service. The realization is that they remain key drivers of these reform initiatives.

2. The study recommends the adoption of a holistic approach of manpower and succession planning aimed at replacing aging workforce with competent, skilled and technologically compliant youthful workforce.

3. Finally, there is obvious need to initiate and unlock more reform benefits through public gazettes and acts of parliament that has a Long Term Evolution (LTE) standard for efficiency and effectiveness of reform initiatives.

\section{Acknowledgement}

The author acknowledges and deeply appreciates the Nigerian Tertiary Education Trust Fund (TETFund), for funding this study through the institution-based research (IBR) fund intervention. 


\subsection{References}

Adamolekun, L. (2002). Africa's Evolving Career Civil Service Systems: Three ChallengesState, Continuity, Efficient Service Delivery and Accountability. International Review of Administrative Sciences, 68 (3), 373-88.

Adewunmi, F., \& Idowu, W. (2012). Public Sector Reforms in Africa: Nigerian Perspectives, Dakar, CODESRIA, 2012, 136 p., ISBN: 978-2-86978-538-0

Ali'nska, A., Filipiak, B. Z., \& Kosztowniak, A. (2018). The Importance of the Public Sector in Sustainable Development in Poland. Sustainability, 10, 1-24.

Anazodo, R. O., Okoye, J. C., \& Chukwuemeka E. E. O. (2012). Civil service reforms in Nigeria: The journey so far in service delivery', American Journal of Social and Management Sciences ISSN Print: 2156-1540, ISSN Online: 2151-1559, doi:10.5251/ajsms.2012.3.1.17.29 (C) 2012, ScienceHuß, http://www.scihub.org/AJSMS

Ayee, J.R.A (2005). Public Sector Management in Africa.AFDB Economic Research Working Paper No. 82, November 2005

Barungi, B. (2014). Nigeria 2014' African Economic Outlook. AFDB, OECD, UNDP 2014

El-Rufai, N. A. (2011) Reforming our Dysfunctional Public Service. Available at http://elombah.com/index.php/articles/nasir-el-rufai/8339-reforming-ourdysfunctionalpublic-service-nasir-el-rufai-v15-8339

Fidrmuc, J. \& Noury, A. (2003). Interest Groups, Stakeholders, and the Distribution of Benefits and Costs of Reform. Being a paper presented at the GDN Workshop on 'Understanding Reform' in Cairo on January 16-17, 2003

Gerth, H. H. and Wright M.C. (eds.) (1946). From Max Weber: essays in sociology. New York: Oxford University Press.

Gruening, Gernod (2001). Origin and Theoretical Basis of the New Public Management (NPM). International Public Management Journal - INT PUBLIC MANAG J. 4. 1-25. 10.1016/S1096-7494(01)00041-1.

Gurara, D., Klyuev, V., Mwase, N., Presbitero, A., Xu, X. C., \& Bannister, G. (2017). Trends and Challenges in Infrastructure Investment in Low-Income Developing Countries. IMF Working Paper, 1-31.

Hamid, K. T. (2013), 'Good Governance and New Public Sector Financial Management Reform in Nigeria' Being a Paper Presented at the Executive Mandatory Professional Training Programme for Fellows of the Chartered Institute of Finance and Control of Nigeria (CIFCN), with the Theme "New Public Sector Financial Management Reform: A Panacea or Placebo for Transparency and Accountability in Nigeria", held in Abuja on $15^{\text {th }}$ and $16^{\text {th }}$ June, 2013. 
IEG (2009). Uganda Country Assistance Evaluation 2001-7 Fast Track Brief, Innovations and Best Practices in Public Sector Reforms: The Case of the Civil Service in Ghana, Kenya, Nigeria and South Africa, Economic Commission for Africa (2010).

Katsamunska, P. (2012). Classical and Modern Approaches to Public Administration' Economic Alternatives, Issue 1, 2012

Maesschalck, J. (2004). The impact of new public management reforms on public servants' ethics Towards a theory. Public Administration, 82, 465-489.

Mbecke, P. (2016). Promoting Socio-Economic Development through Public

Entrepreneurship: A Conceptual Perspective. Socioeconomica-The Scientific Journal for Theory and Practice of Socio-economic Development, 5(9), 93-108.

Monye-Emina, A. I. (2012). Theoretical Basis of Public Sector Reforms in Nigeria: A General Critique

Monye-Emina, A.I. (2012). The Theoretical Basis of Public Sector Reforms in Nigeria: A General Critique, Public Sector Reforms in Africa: Nigerian Perspectives. Edited by Funmi Adewumi \& William Idowu. Dakar, CODESRIA, 2012, 136 p., ISBN: 978-286978-538-0

Ojeifo, A., \& IleSanmi, A. G. (2015). Public Enterprise and Sustainable Socio-Economic Development in Nigeria. Review of Public Administration and Management, 4(8), 5162.

Okonjo-Iweala, N. (2012). Reforming the Unreformable: Lessons from Nigeria, Cambridge Massachusetts, MIT Press.

Olaopa, T. (2013) 'Reflection on Bureau of Public Service Reform, http//www.tunjiolaopa.com

Olaopa, T. (2013). A Critical Overview of Public Sector Reform in Nigeria: Framework of Transformation for The Federal Civil Service', http//www.tunjiolaopa.com/

Omoyefa, P. S. (2008). Public Sector Reforms in Africa: A Philosophical Re-Thinking. Africa Development, 10(4), 15-30

Pollitt, Christopher \& Bouckaert, Geert (2004). Public Management Reform: A Comparative Analysis, second edition (Oxford: Oxford University Press).

Rodman, P. W. (1968). Development Administration: Obstacles, Theories and Implications for Planning. IIEP Occasional Papers No. 2, December 1968

Scott, Z. (2011). Evaluation of Public Sector Governance Reforms 2001-2011: Literature Review', Oxford Policy Management Organization, http://www.opml.co.uk ; http://www.gsdrc.org/docs/open/scott2011_PSGRLiteraturereviews.pdf 
Journal DOI: $\underline{\text { www.doi.org/10.46654/AJBED }}$

Vol. 1, Issue 2 (February, 2021) | www.ijaar.org

Article DOI: www.doi.org/10.46654/AJBED.1218

Therkildsen, O. (2001). Efficiency, Accountability and Implementation Public Sector Reform in East and Southern Africa. Democracy, Governance and Human Rights Programme Paper No. 3, February 2001 